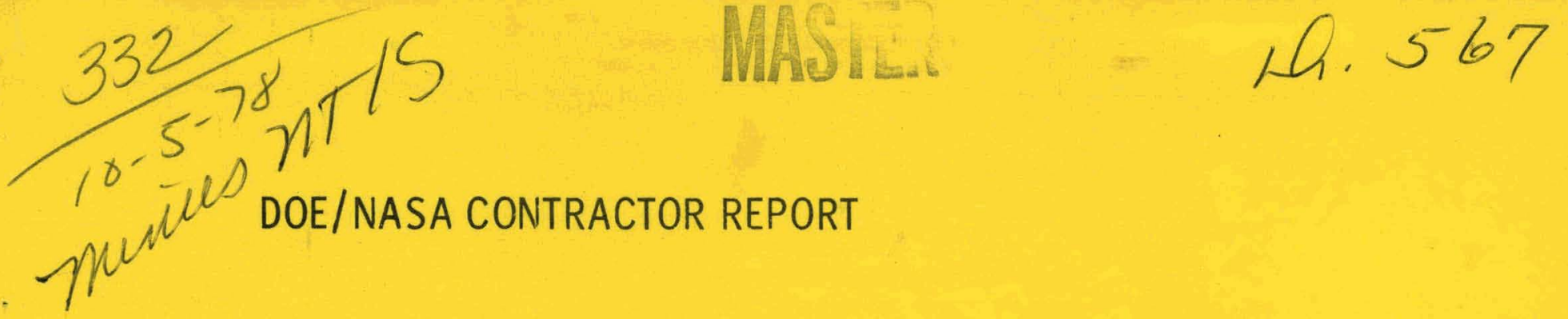

DOE/NASA CR- 150525

\title{
QUARTERLY REPORTS ON PROTOTYPE SOLAR HEATING AND HOT WATER SYSTEMS
}

Prepared from documents furnished by

Colt, Inc. of Southern California

71-590 San Jacinto Drive

Rancho Mirage, California 92270

under Contract NAS8-32242 with

National Aeronautics and Space Administration

George C. Marshall Space Flight Center, Alabama 35812

for the Department of Energy

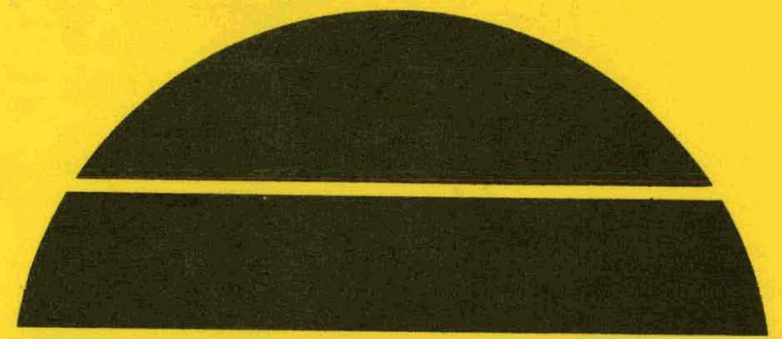

\section{U.S. Department of Energy}




\section{DISCLAIMER}

This report was prepared as an account of work sponsored by an agency of the United States Government. Neither the United States Government nor any agency Thereof, nor any of their employees, makes any warranty, express or implied, or assumes any legal liability or responsibility for the accuracy, completeness, or usefulness of any information, apparatus, product, or process disclosed, or represents that its use would not infringe privately owned rights. Reference herein to any specific commercial product, process, or service by trade name, trademark, manufacturer, or otherwise does not necessarily constitute or imply its endorsement, recommendation, or favoring by the United States Government or any agency thereof. The views and opinions of authors expressed herein do not necessarily state or reflect those of the United States Government or any agency thereof. 


\section{DISCLAIMER}

Portions of this document may be illegible in electronic image products. Images are produced from the best available original document. 
This report was prepared to document work sponsored by the United States Government. Ne1ther the United States nor 1 ts agents the Unfted States Department of Energy, the United States National Aeronautics and Space Adminfstration, nor any federal employees, nor any of their contractors, subcontractors or their employees, make any warranty, express or 1mplied, or assume any legal liabllity or responsibility for the accuracy, completeness, or usefulness of any information, apparatus, product or process disclosed, or represent that 1ts use would not infringe privately owned rights. 
TECHNICAL REPORT ST ANDARD TITLE PAGE

\begin{tabular}{|c|c|c|}
\hline $\begin{array}{l}\text { 1. REPORT NO. } \\
\text { DOE/NASA CR-150525 }\end{array}$ & 2. GOVERNMENT ACCESSION NO. & 3. RECIPIENT'S CATALOG NO. \\
\hline \multirow{2}{*}{\multicolumn{2}{|c|}{$\begin{array}{l}\text { 4. TITLE AND SUBTITLE } \\
\text { Quarterly Reports on Prototype Solar Heating and Hot Water } \\
\text { Systems }\end{array}$}} & $\begin{array}{l}\text { 5. REPORT DATE } \\
\text { January } 1978\end{array}$ \\
\hline & & 6. PERFORMING ORGANIZATION CCIDE \\
\hline 7. AUTHOR(S) & & 8. PERFORMING ORGANIZATION REPOR I \# \\
\hline \multirow{3}{*}{\multicolumn{2}{|c|}{$\begin{array}{l}\text { 9. PERFORMING ORGANIZATION NAME AND ADDRESS } \\
\text { Colt. Inc. of Southern California } \\
71-590 \text { San Jacinto Drive } \\
\text { Rancho Miräge, California } 92270\end{array}$}} & 10. WORK UNIT. NO. \\
\hline & & $\begin{array}{l}\text { 11. CONTRACT OR GRANT NO. } \\
\text { NAS } 8-32242\end{array}$ \\
\hline & & \multirow{2}{*}{ 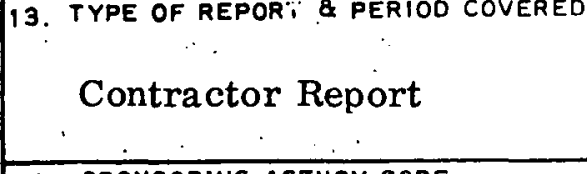 } \\
\hline \multirow{2}{*}{\multicolumn{2}{|c|}{$\begin{array}{l}\text { 12. SPONSORING AGENCY NAME AND ADORESS } \\
\text { National Aero nautics and Space Administration } \\
\text { Washington, D. C. } 20546\end{array}$}} & \\
\hline & & 14. SPONSORING AGENCY CODE \\
\hline
\end{tabular}

15. SUPPLEMENTARY NOTES:

This work was done under the technical management of Mitchell Cash, Marshall Space Flight Center, Alabama.

16. ABSTRACT

This report contains four quarterly reports that cover the progress made in the development of a solar hot water and space heating system. It provides the program schedules, technical status and other program activities from October 6, 1976 through September 30, 1977.

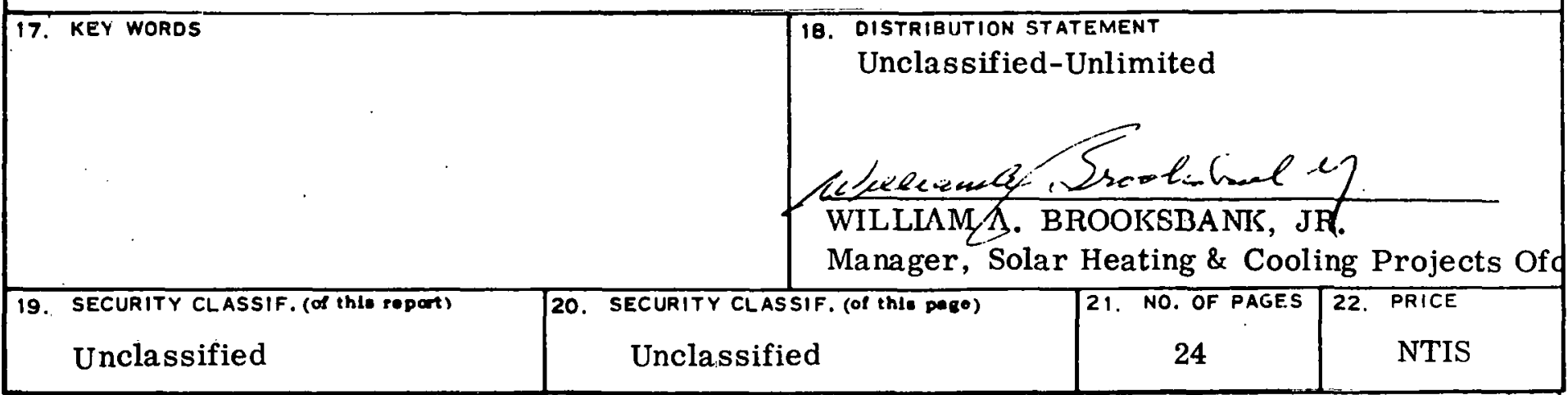




\section{INTRODUCTION}

This document is a collection of four quarterly status reports from Colt, Inc. , covering the period from October 6, 1976, through September 30, 1977. Colt, under NASA/MSFC Contract NAS8-32242, is developing two prototype solar heating and hot water systems consisting of the following sub-systems: collector, storage, control, transport, hot water, and auxiliary energy.

The two systems are being inctalled at Yosemite, California and Pueblo, Colorado.

Cost information has been removed. 
First Quarterly Status Report

COLT HEATING \& HOT WATER HEATING SOLAR PROGRAM

NASA Contract NAS8-32242

For the Time Period

October 6 to November 30, 1976

\section{GLT INC. OF SOUTHERN CALIFORNIA}

ENERGY SYSTEMS DIVISION

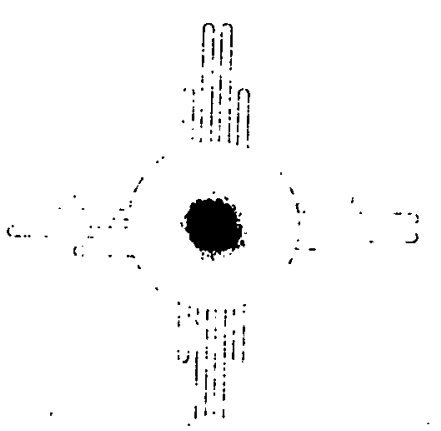

December 7, 1976

This report was prepared as an account of work sponsored by the United States Government. Neither the United States nor the United States Department of Energy, nor any of their employees, nor any of theit contractors, subcontractors, of their employees, makes any warranty, express or implied, or assumes any legal liability or responsting for the aceurs

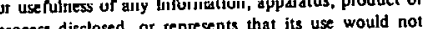

process disclosed, or represents that its use would not infringe privately owned rights.

\section{COIT INC. OF SOUTHERN CALIFORNIA}

71-590 San Jacinto Drive Rancho Mirage, California 92270

Tat

Paul S. Wheeler

Project Engineer

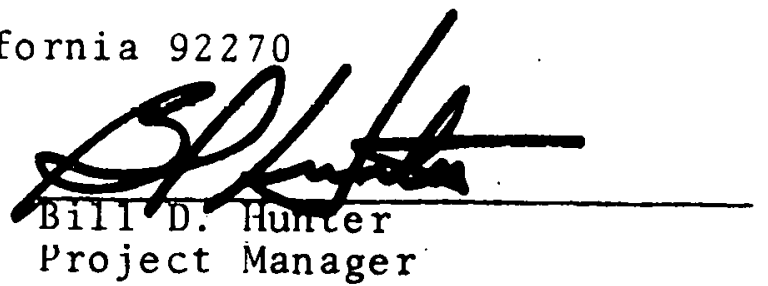

WISTELOUTON OF THIS DOCUMENT IS UNLIMTED 
1.0 Summary

This is the first quarterly progress report under NASA Contract NAS8-32242 to Colt Inc. for the development of a solar hot water heating and space heating system. This report covers the period from October 6 to December 6, 1976, a period of two months. This report provides a status of current scheduling and provides an inclusive summary of the current technical status.

2.0 Contract

This paragraph has been deleted.

3.0 Schedules

Figure 2 shows the current program schedule, which is a compressed schedule to permit implementation of deliverable hardware at the operational test sites for the 1977 heating season. Colt is proceeding on this schedule without slippage, nor the. requirement for internal schedule adjustments.

\subsection{Technical Performance}

Three of the four design uncertainties identified in the Colt proposal have been analyzed and incorporated into the design to the exterit that they are no longer considered uncertainties. 


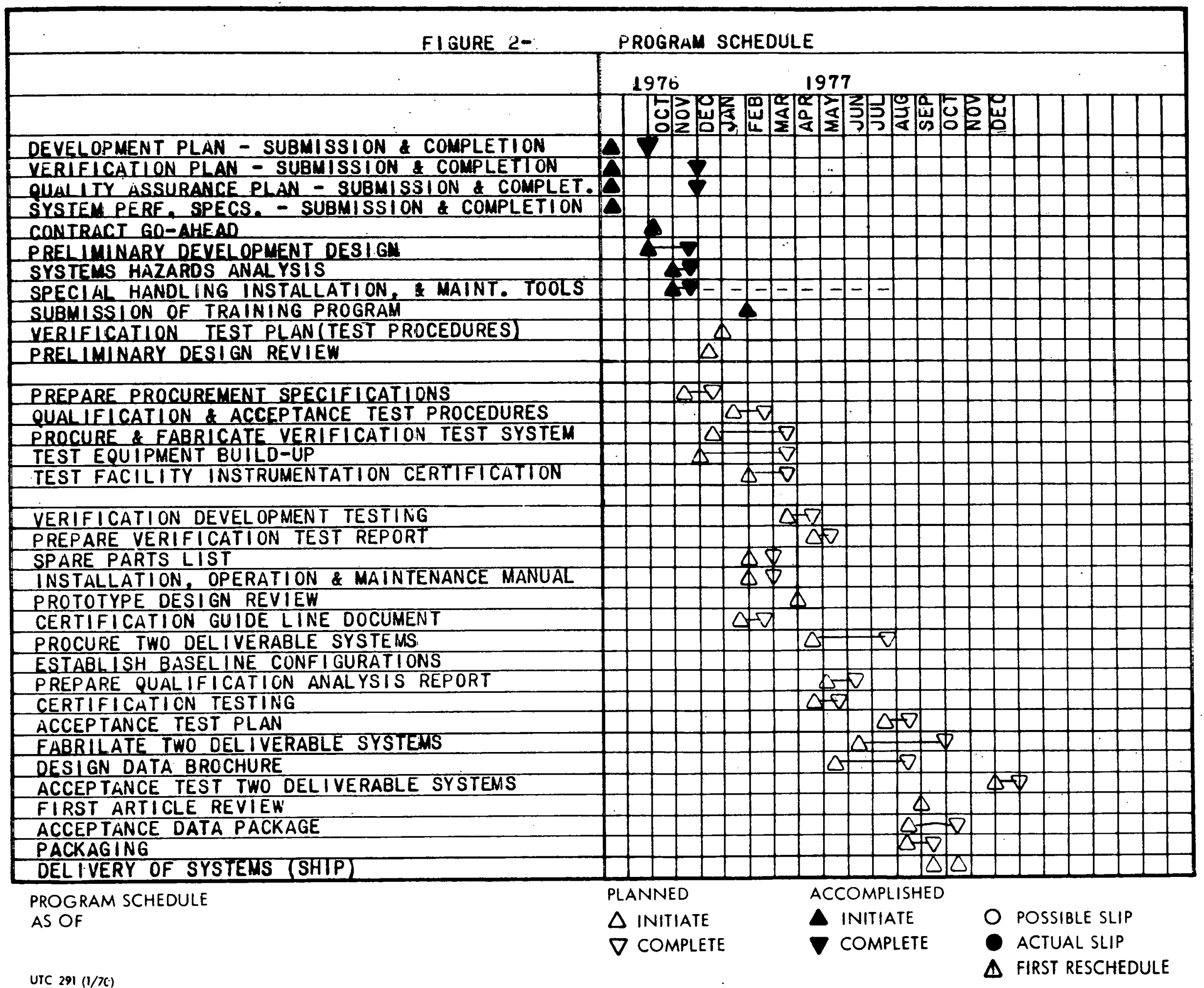


The first uncertainty was the selective surface coating versus a painted surface when considering single and double layers of glazing. The selective surface and a single layer of glazing was chosen because of performance and cost. Previous test data has shown this combination to be substantially better than the double glazing with the nonselective surface.

The second uncertainty was the steel thermal starage tank. The trade-off being considered was the cost of the steel tank versus lower cost alternatives. It was agreed in contract negotiation to implement a lower cost, concrete tank in the Colt verification system, and a steel tank to be in one of the operational test sites. Cost and performance data is now available on both tank configurations. The concrete tank, whe re available geographically, will be an economic advantage in selection.

The third uncertainty involved a flexible connection from the collector to the collector manifold. The decision has been made to go with all copper manifolds and connections. These connections will be $1 / 2$ " tubing which will be installed with a gradual radius to provide for flexing during thermal expansions .

The fourth uncertainty involved the thermostat tolerances which are yet to be assessed during Verification Development 
Testing.

The major design activities have been centered around meeting the requirements for the Preliminary Design Review and establishing the configuration for Verification Testing. The collector design was modified to incorporate an isolated collector surface from the supporting structure. The collector width was decreased to permit installation between roof joists $24^{\prime \prime}$ on center. The heat exchanger designed for the thermal storage tank was finalized. The design incorporates four (4) flat, plate coil heat exchangers manifolded into a single bank unit to be placed on the bottom of the thermal storage tank.

Colt has elected to use, in every instance possible, the same instrumentation in Verification Development Testing that will be used for the Operational Test Sites. This has resulted in a change in Verification Development Test instrumentation; however, this change is expected to provide an easier transition from Verification Testing to the configuration that will be employed at the Operational Test Sites.

The forecast of coming activities shows the preliminary design review as being of primary significance in that, during this review, it is anticipated that the Operational Test Sites will be named. Coordination for installation at the Operational Test Sites is expected to be a major undertaking. The second 
significant activity taking place in the forthcoming quarter will be the procurement and initial installation of the Verification Test equipment.

There are currently no anticipated problems or difficulties on the solar program. All activities are proceeding without problems or slowups.

The following data has been submitted during this reporting period:

1. Preliminary Training Program

2. Quality Assurance Plan

3. Verification Plan

4. System Hazards Analysis

5. Colt Interface with the Proposed Instrumentation Plan

6. Special Handling, Installation, Maintenance and Tools List

7. Recommendations for Prototype Design Review

8. Component Materials in Contact with Heat Transfer Fluid

There were no meetings or travel involved in this reporting period.

There have been no tests conducted during this reporting period. 
Second Quarterly. Status Report

COLT HEATING \& HOT WATER HEATING SOLAR PROGRAM

NASA Contract NAS8-32242

For the Time Period

December 1, 1976 through February 28, $1977^{\circ}$

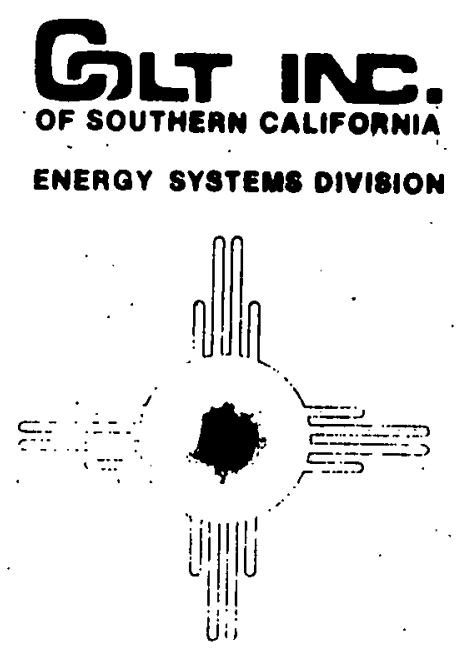

March 22, 1977

COLT INC. OF SOUTHERN CALIFORNIA

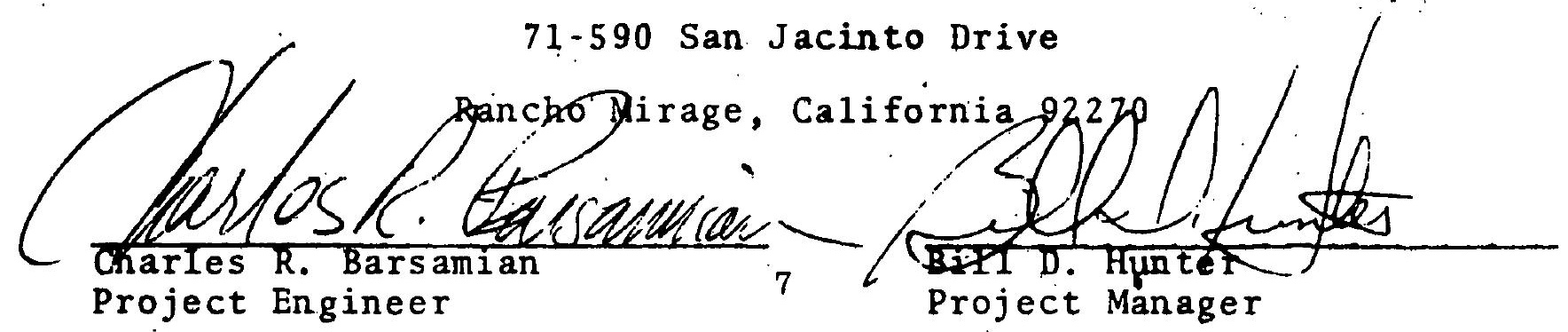




\subsection{Summary}

This is the second quarterly progress report under VASA Contract iNAS8-32242 to Colt, Inc. for the development of a solar hot water heating and space heating system. This report covers the period from December 1, 1976 to February 28, 1977, a period of three months. This report provides a status of current scheduling and provides an inclusive summary of the current technical status.

2.0 . Contract

There is currently one change proposal (PCN AH-00209) under submittal to NASA for certification testing. The assignment of Contractor Code was received on December 17 , 1976. The Review Item Discrepancies from the Preliminary Design Review were received on December 16, 1976 with NASA signature.

\subsection{Sciledules}

Figure 2 shows the current program schedule, which is a compressed schedule to permit implementation of deliverable hardware at. the Operational Test sites for lie 1977 lieuling season. Colt is proceeding on this schedule with some slippages created by manufacturers' delivery times. Adjustments are being made to maintain operational site delivery schedule. 
DEVELOPMENT PLAN - SUBMISSION \& COMPLETION VERIFICATION PLAN - SUBMISSION \& COMPLETION

QUAL IIY ASSURANCE PLAN - SUBMISSION \& COMPLET. SYSTEM PERF. SPECS. - SUBMISSIICN \& COMPLETION CUNIRACT GO-AHEAD

PREL IMINARY DEVEL OPMENT DESIEN

SYSTEMS HAZARDS ANAL YSIS

SPECIAL HANDLIN'G INSTALLATION, \& MAINT. TOOLS

SUBMISSION OF TRAINING PROGRAM

VERIFICATION TEST PLAN(TEST PROCEDURES)

PRELIMIINARY DESIGN REVIEW

PREPARE PROCUREMENT SPECIFICÁTICNS

QUALIFICATION \& ACCEPTANCE TEST PROCEDURES

PROCURE \& FABRICATE VERIFICATION TEST SYSTEM TEST EQUIPMENT BUILD-UP

TEST FACILITY INSTRUMENTATION CERTIFICATION

VERIFICATION DEVEL OFNENT TES ${ }^{-}$ING

FRE $Y A R E$ VERIFICATION TEST REFURT

S.PATE PARTS LIST

IIISTALLATION, OPERATIOIN \& MAINTENANCE MANUAL

PROTOTYPE DESIGN REVIEli

CERTIFICATION GUIDE LINE DOCUMENT

PROCURE TWO DEL IVERABLE SYSTEMS
ESTABLISH BASEL INE CCNF I GURATIONS

FREFARE QUAL IFICATION ANALYSIS REFORT

CERTIFICATICN TESTIRIG

ACCEPTANICE TEST PLAN

FABRILATE TWO DELIVERABLE SYSTEMS

DESIGN DATA BROCHURE

ACCEPTANCE TEST TWO DEL IVERABLE SYSTEMS

FIRST ARTICLE REVIEV'

ACCEPTHNCE DATA PACKAGE

PACKAGING

DELIVERY OF SYSTEMS (SHIP)

PROGRAM SCHEDULE

AS OF

UTC $291(1 / 70)$

$1570 \quad 1977$

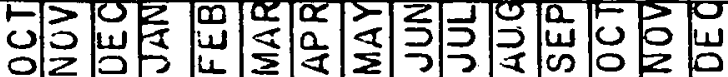

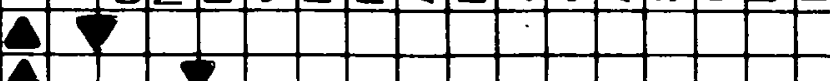

A

2

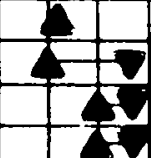

Sy-

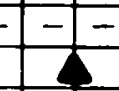

a
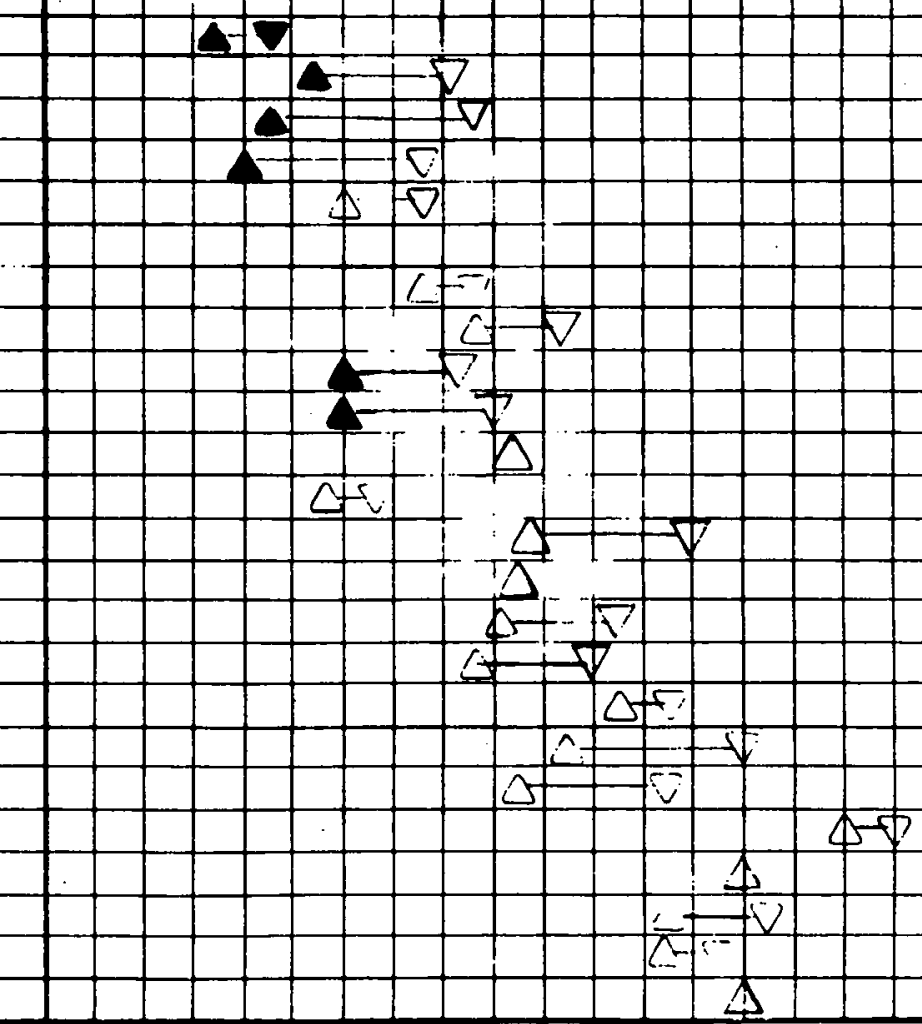

PLANNED

$\triangle$ INITIATE

$\nabla$ COMPLETE
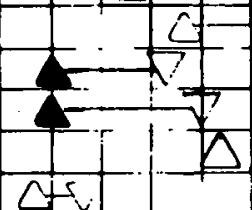

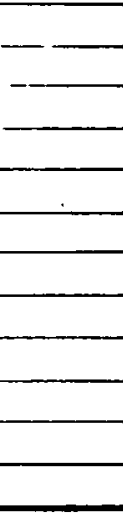

1

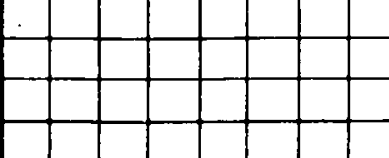

ACCOMPLISHED

- INITIATE

$\checkmark$ COMPLETE
O POSSIBLE SLIP

- actual slip

$\triangle$ FIRST RESCHEDULE 


\subsection{Technical Performance}

The last design uncertainly identified in the colt proposal involving room the rmostat temperature spreads has been analyzed and solved. The solution has been incorporated into the design. The proposal referred to the twu-slage thermostat tolerances currently known to be available, advising that the temperature spread could likely not be in the customary comfort range. The uncertainty has becn resolved by incorporating a second Temperature Switch within the control circuit and by eliminating the second stage within the the rmostat. This combination will provide even heating without the annoying "room cool down" necessary to activate the second stage within the thermostat.

The major design activities have been contered around the Verification Testing System buildup. All purchase orders were negotiated and placed with component vendors. Excessive supply lead times for some components has forccd a later cumpletion date than was originally anticipated. The schedule reflects currently expected completion dates: The Solar Test Facility was constructed and is complete except for the installation of the collector panels and reiated manifolding.

The Data Acquisition equipment was received and has been 
installed and tested. Instrumentation connection is being readied for installation and the logic for test programing is being prepared.

The Visitors' Center East Auditorium in the Yosemite National Park has been selected as one Operational Test Site. Preliminary concept and architectural integration designs have been generated for current review. The forecast of coming activities shows the completion of the verification test systemand test commencement as being of primary significance. A second significant endeavor will be the approval of the Yosemite design and selection of the second operational test site.

There are currently no difficulties being encountered. No data has been submitted during this reporting period nor have there been any tests conducted.

The Preliminary Design Review meeting and Quarterly Design Review meeting was held on December 20, 1976 at the Colt facility. Those present were:

Mr. Mitch Cash, iNASA

Mr. Irwin Simon, NASA

Mr. Val Foge1, NASA

Mr, Stan Vioore, Los Alamos Scientific Laboratories

Mr. Bill Hunter, Colt, Inc.

Mr. Daul Wheeler, Colt, Inc. 
This Second Quarterly Review was held at Yosemite in conjunction with a coordination meeting at the proposed Yosemite Operational Test Site. The point was made that NASA was limited on funds and could not fund the certification testing as proposed by Colt. It was agreed that certification of performance would be an outgrowth of NASA's system performance evaluation of the operational test site via the site data acquisition system if the certification program is not funded by NASA. In general terms, the possibility of Colt obtaining independent laboratory certification of the system's safety was discussed. If undertaken, the safety certification will be out of the contracted program scope and would be an expense to Colt. 
Third Quarterly Status Report

COLT HEATING \& HOT WATER HEAT ING SOLAR PROGRAM :

NASA Contract NAS $8-32242$

For the Time Period

April 1, 1977 thru.June 30, 1977

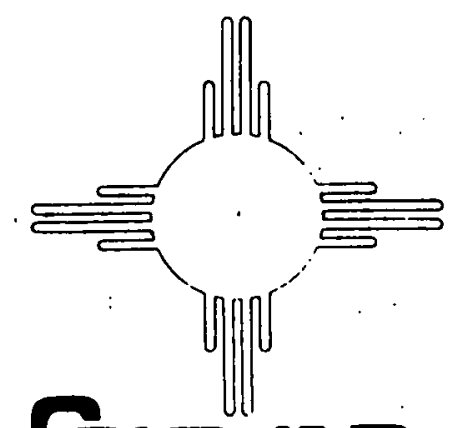

G Tr. Ins.

EMEROY BYSTEMS DIVISION

$$
\text { July } 13,1977
$$

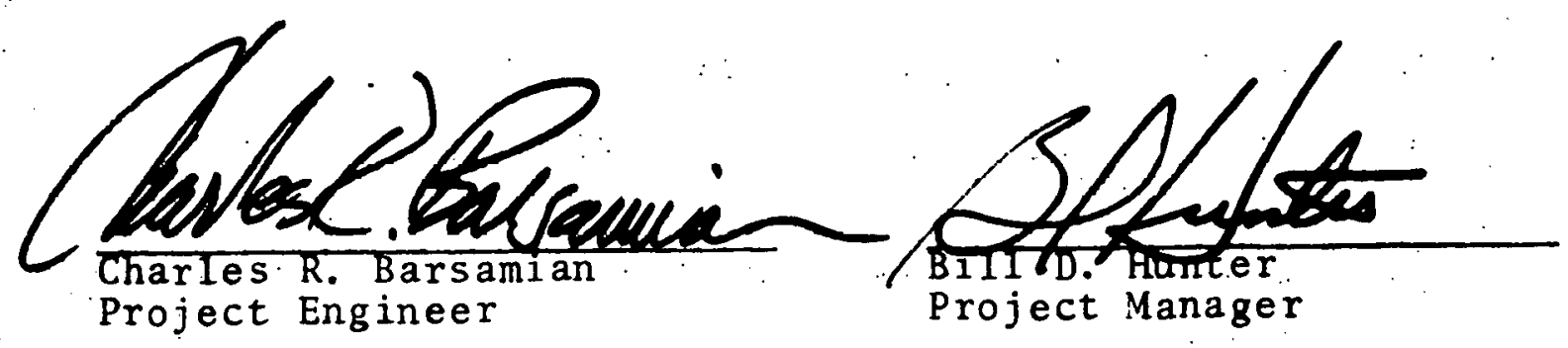

71-590 SAN JACINTO DRIVE/RANCHO MIRAGE, CALIFORNIA 92270 (714) 346-8033 


\section{0 Sunmary}

This is the third Quarterly Progress Report under NASA Contract NAS 8-32242 to Colt Inc. for the development of a sular hot water heating and space heating system. This report covers the period from April. 1; 1977 to June 30, 1977, a period of three months. This report provides a status of current scheduling and provides an inclusive summary of the current technical status.

\subsection{Contract}

The Prototype Design Review was conducted at the Colt facility on May 9, 1977. Review Item Discrepancies \#Colt $20-39$ were delivered and discussed during this review. Subsequently received was RID \#Colt 40 . Colt indicated actions taken and resubmitted these RID's on June 8, 1977.

line Prototype Design Review was conducted at the Colt Eacility on May 9, 1977. Those in attendance were:

$$
\begin{aligned}
& \text { Mr. Hitcil Cash, NASA } \\
& \text { Mr. Bill Hunter, Colt Inc. } \\
& \text { Mr. Chuck Barsamian, Colt Inc. }
\end{aligned}
$$

The collector problems involving cost and weight were discussed during the review, as were the RIID's fColt $20-39$. The Yosemite project scheduling was also discusscil.

A second Design Review was conducted at the Colt facility on June 28, 1977, to cover design changes in the collector 
made by Colt. lhose in attendance were:

Mr. Mitch Cash, NASA

Mr. Erwin Simon, NASA

Mr. Dwight Wende11, National Park Service

Mr. Bill Hunter, Colt Inc.

ivr. Paul Wheeler, colt Inc.

Mr. Chuck Barsamian, Colt Inc.

The RID's \#Colt 41 - 51, concerning the collector redesign; were discussed and appropriate suggestions made. Colt has indicated the action taken in each case and will resubmit these RID's on July 13, 1977, for approval.

Also discussed, during this review, was the Yosemite Operational Test Site installation schedule. This scheduling was of major concern as current bidding and construction time might prohibit the targeted collector installation before first snow fall.

There are currently no change proposals in progress.

\subsection{Schedules}

ligure 2 indicates the current program schedule. Colt is proceeding on this schedule without slippage. However, this schedule had been previously adjusted to reflect sippages caused by excessive manufacturers' lead times 


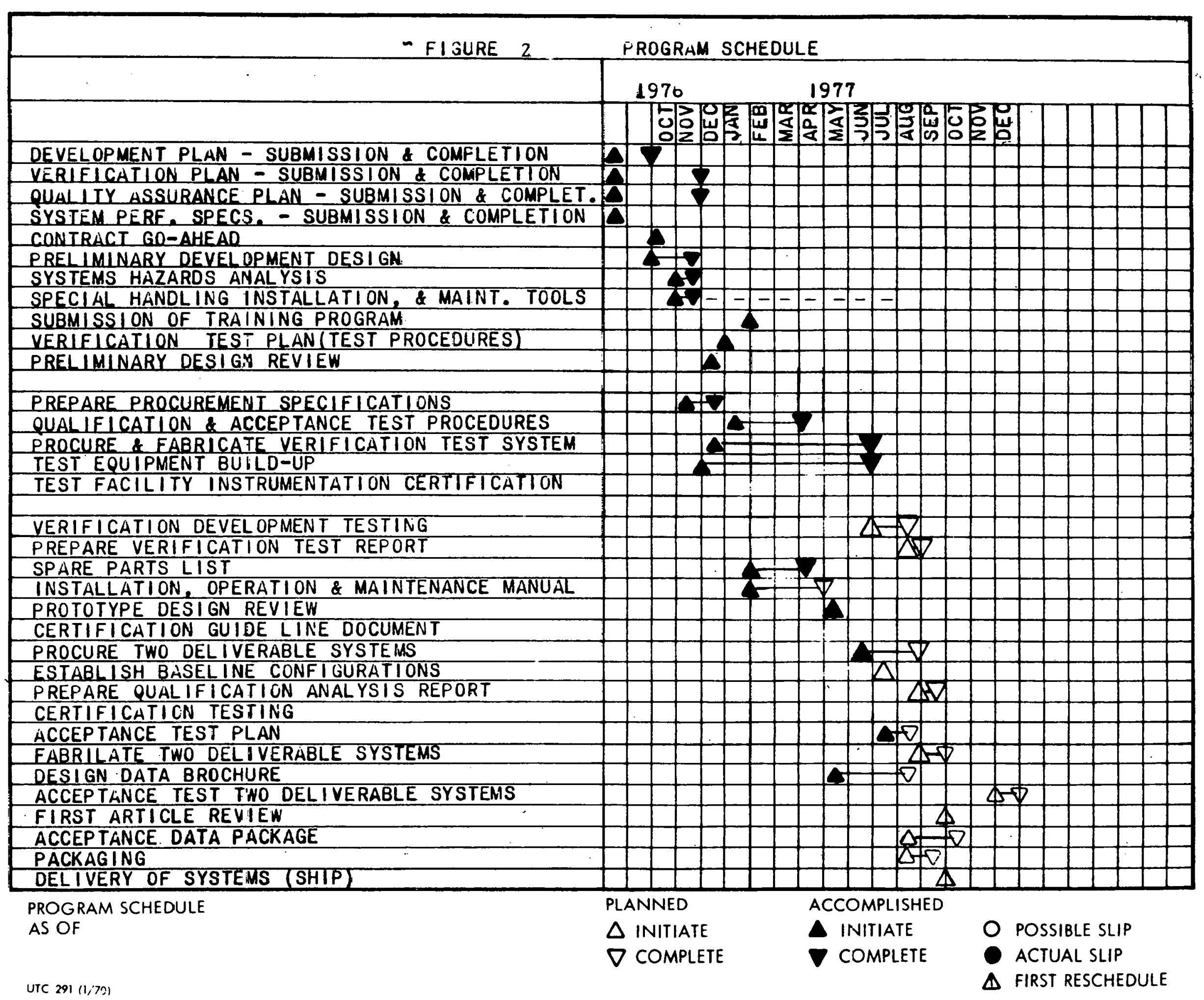


and also severe damage incurred during sinipment of compo* neint parts to Colt:

\subsection{Technical Status}

The overall technical status is progressing without difficulty. Verification 'Test hardwarc buildup has proceeded according to internal scheduling and is complete. The data acquisition equipment and instrumentation with related temperature and flow sensors has been installed and programined for information retrieval. Initial program testing and lebugging has been conducted.

The Colt collector is in the final stage of the redesign neccsitated by excessive weight and cost of the original steel panel and housing. The new collector will be tested, and all results will be compared to existing efficiencies which will be determined by Verification Testing of the prosent Colt collector.

The Amtrac High Speed Test Facility in Pueblo, Colorado, has tentatively been selected as the second Uperational Test Site.

The following data has been subitted during this reporting period:

Al1 Schematic and Fingineering drawings

The Verification Status Summary 
The amended Verification Status Summary

The Installation, Operation $\&$ laintenance Manual outline

The System Installation drawings

The Spare Parts 1 ist.

This Third Quarterly Review was held at the Colt Facility in Rancho Mirage on August 5, 1977. Those in attendance were:
Mr. Mitch Cash, NASA
Mr. John Hassey, NASA
Mr. Paul Wheeler, Colt Inc.
Mr. Charles Barsamian, Colt Inc.

Mr. Cash raised several areas of concern with the installa. tion scheduled for the Yosemite Operational Test Site. These were discussed and solutions were suggested and will be acted upon by colt Inc. Plans were made for a Design Review to be conducted at Yosemite on August 10 .

Also discussed during this review were the preliminary. drawings for the Pueblo Installation. An Angust 30 design review was scheduled. October 3 has been set as the tentative date for the First Article Review,

Performance and Safety Certification was discussed. Colt Inc. will gather information and make preliminary arrangements to certify toth the performance and safety of the Verification Test Ilardware Instaliation at Rancho Mirage. 
Fourth Quarterly status Report

COLT HEATING \& HCT WATER HEATING SOLAR PROGRAM

NASA Contract NAS $8-32242$

lFor the Time Period

July 1, 1977 thru September 30,1977
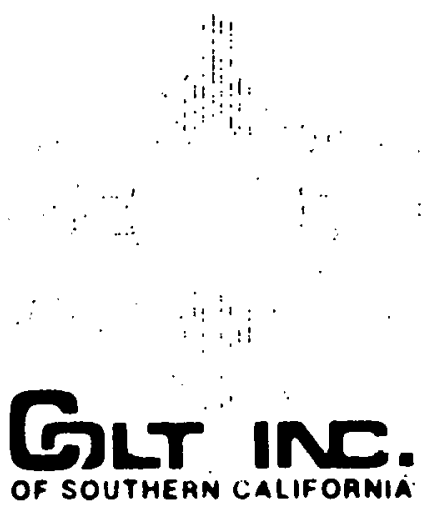

ENFHG SYSTEMS DIVISION

November 21, 1977
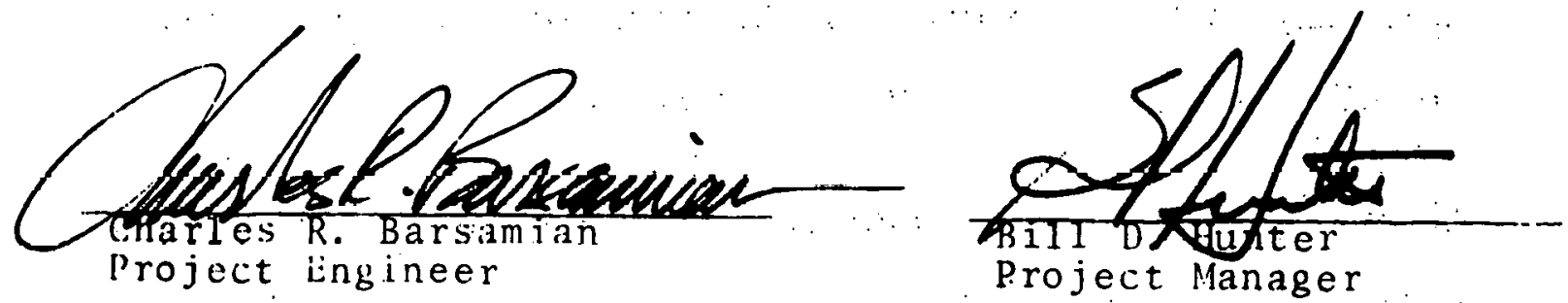

71590 SAR, JAGINTO DHIVF/RANCHO MIIKAGE. CALIFORINIA 9:2.270 (714) 346.80.13:3 


\subsection{Summary}

This is the Fourth Quarterly Progress iejort under NASA Contract NAS 8-32242 to Colt Inc. for the development of a solar hot water heating and space heating system. This report covers the period from July 1, 1977 to September 30, 1977, a period of three months. This report provides a status of current scheduling and provides. an inclusive summary of the current technical status.

\subsection{Contract}

A Design Review was conducted at the Yosemite Operational Test Site on August 10, 1977. Those in attendance were: Mr. Les Arnberger, Yosemite National Park Mr. Zoltan Muttnyansky, West. Reg. Off., Nat'1 Parks Scrvice Mr. Mark Cardosa, Creegan \& 'D'Angelo, San Jose, CiA Mr. Dwight Wendell, National Parks Service, Denver, CO Mr. Bob Gunner, NASA, Marshall Space Flight Center, $\Lambda$ ! Mr. Mitch Cash, NASA, Marsholl Spare Flight Conter, Ml. Mr. Bill Rothchild, National Parks Service, Denver, (i) Mr. Tom Hayes, Spa Plumbing Mr. Paul Wheeler, Colt Inc.

Building moditications and the location of the Thermal storago Building were discussed and finalized.

A. lesign Review was conducted at the Pueblo uperational Test Sitc on August $31,1977$. 
The Thermal Storage vessel location was discussed and finalized. Decisions regarding specific component suppliers were discussed and finalized. The installation contractor was chosen and is:

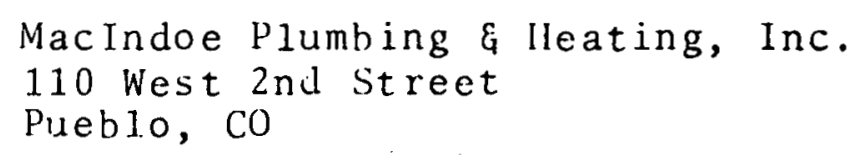

A Design Review was conducted at the Colt Facility on Septunber 15, 1977. Those in attendance were:

Hr. Mitch Cash, NASA, Marshall Space Fight Center

Mr. Bill Ilunter, Colt Inc., Rancho Mirage

Mr. Charles R. Barsamian, Colt Inc., Rancho Mirage (iencral design modifications wore discussed and implemented.

\section{0 schedules}

ligure 2 indicates the current program schedule. Colt Inc. is procecding on this schedule without slippage. However this schedulc has been previously adjusted to reflect the following:

a) Slippage caused by the colt collector redesign

b) Slippage in the National Park Service schedule for building modification.s

c) Slippage in the Department of Transportation schedule for building modifications.

\subsection{Technical Stiatus}

The overall technical status is proyressing without difficulty. Verilication Test hardware buildup has been completed.

The data acquistion program has been tested and "debugged." full data collecting and graphing capability has been achieved. 


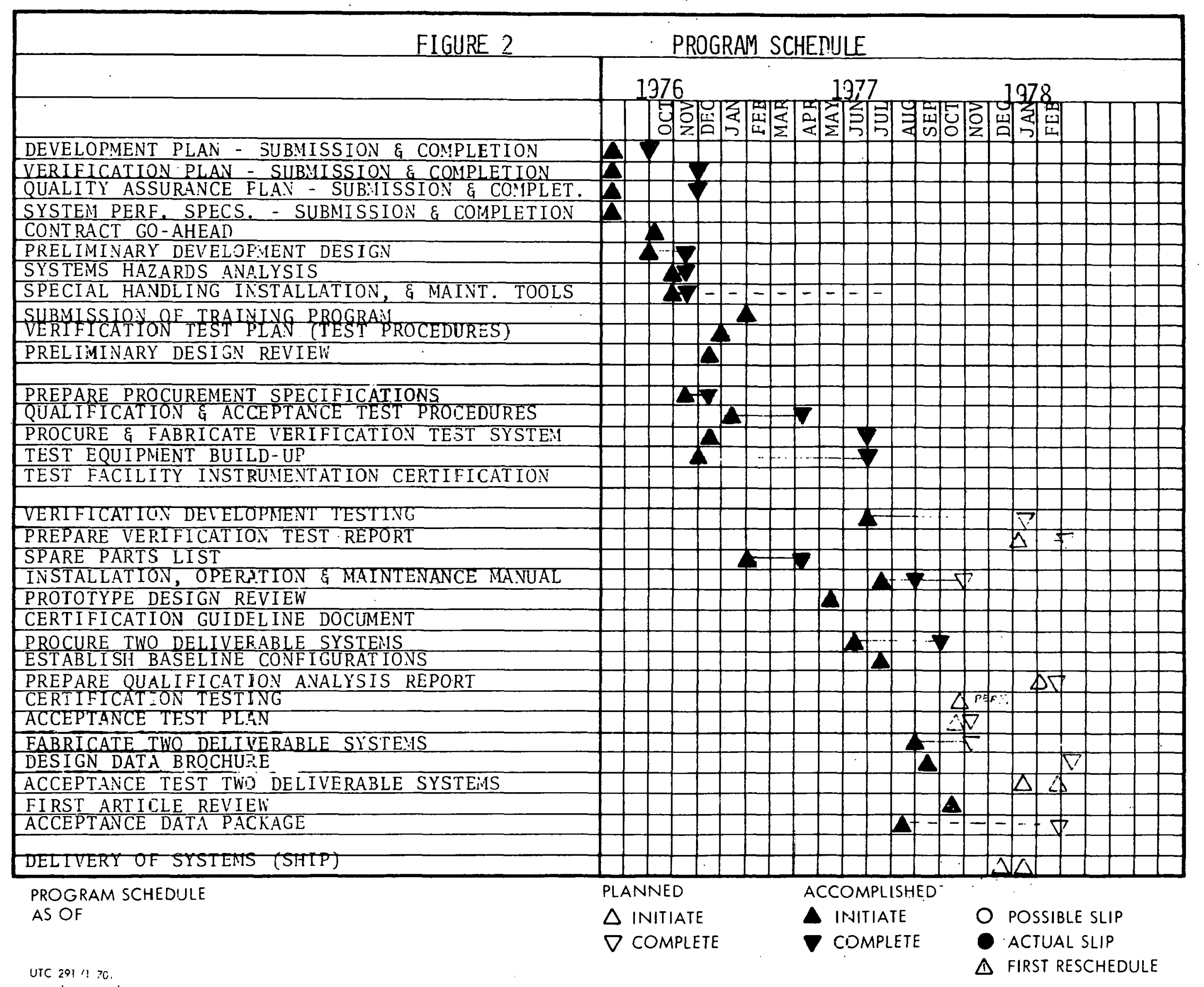


The Amtrac Speed Test Facility in Pueb1o, Coloradowas finalized as the second operational Test Site. The system component hardware was procured and fabricated, in preparation for the First Article Review and shipment to Pueblo.

linal preliminary drawings of the Yosemite Operational Test site were sent to all parties concerned. The Yosemite hardware components were procured and fabrication has been initiated.

The following data has been submitted during this reporting period:

Change proposal \#Allo0342, September 16, 1977. 